\title{
Study of dynamic Impact of Speed Trains on Bridge Structures
}

\author{
Hakim Siguerdjidjene ${ }^{1}$, Leonid Konstantinovich Dyachenko ${ }^{2}$ \\ ${ }^{1}$ Dept. Mechanical Engineering, M'hamed Bougara University, Faculty of Technology, \\ 3500 Boumerdes, Algeria, \\ Laboratory of Materials and Sustainability of Bouira. \\ Siguer1@hotmail.com
}

${ }^{2}$ Dept. Bridges, Emperor Alexander I St. Petersburg State Transport University. leonid_dyachenko@mail.ru

Received: July 17, 2020. Revised: January 20, 2021. Accepted: February 28, 2021. Published: March 4, 2021.

\begin{abstract}
This research presents a study of the dynamic impact of high-speed trains moving on continuous and discontinuous span bridges. As an example of this study, a continuous span ballast bridge project with a total length of $174 \mathrm{~m}$ has been adopted, according to the scheme $27+3 \times 40+27 \mathrm{~m}$, allows us to analyze the dynamic impact of displacement of different trains at a speed range of $100 \mathrm{~km} / \mathrm{h}$ to a maximum speed of $300 \mathrm{~km} / \mathrm{h}$, as well as to make a comparison of the dynamic behavior of this continuous-span HSR bridge from the discontinuous span bridge systems with lengths of $27 \mathrm{~m}$ and $40 \mathrm{~m}$, and draw conclusions about the dependence of the maximum dynamic coefficients and the vertical accelerations at the midpoints of the span bridges as a function of the moving speed of the deferent trains. The resolution of the dynamic problem of moving loads during design and calculation is based on the modeling of the Bridge-Train system by the complex program, realized by the finite element method (FEM). In this work, for the numerical simulation of dynamic problems, Sofistik software was used. The results show that the increase of train speed up to $300 \mathrm{~km} / \mathrm{h}$, it is possible to manifest resonant vibration modes of the structures in span.

The results show that the increase of train speed up to $300 \mathrm{~km} / \mathrm{h}$, it is possible to manifest resonant vibration modes of the structures in span.
\end{abstract}

Keywords - Bridge rail road, high speed train (HST), dynamic vertical accelerations, dynamic coefficient.

\section{INTRODUCTION}

I recent years, Algeria has adopted a policy of diversifying its investments in the field of rail transport infrastructure in order to cope with the insufficiency of means of transport to respond to the increase in the flow of passenger mobility and some products. As well as opening up the still isolated regions and propelling its development dynamic by strengthening and developing the transport sector which is becoming essential and considered as an element of economic and political power, and often described as the economic lung of a country.

In addition, the increase in the flow capacity of people and the speed of their mobility requires an increase in the running speed of trains, which has a dynamic impact (effects) on railway infrastructure and especially on railway bridges (viaducts), hence the need for a study in this area is essential.

\section{I.1. DESCRIPTION OF BRIDGE}

As an example of studying the dynamic impact (effects) of high-speed trains on bridges, a design of a bridge (viaduct) with a total length of $174 \mathrm{~m}$ distributed over 3 central spans at $40 \mathrm{~m}$ span and 2 lateral spans at $27 \mathrm{~m}$ span was adopted, according to the scheme $27+3 \times 40+27 \mathrm{~m}$ (Figure 1). The bridge deck consists in a single cell prestressed concrete box girder supported on reinforced concrete piers and abutments at each end.

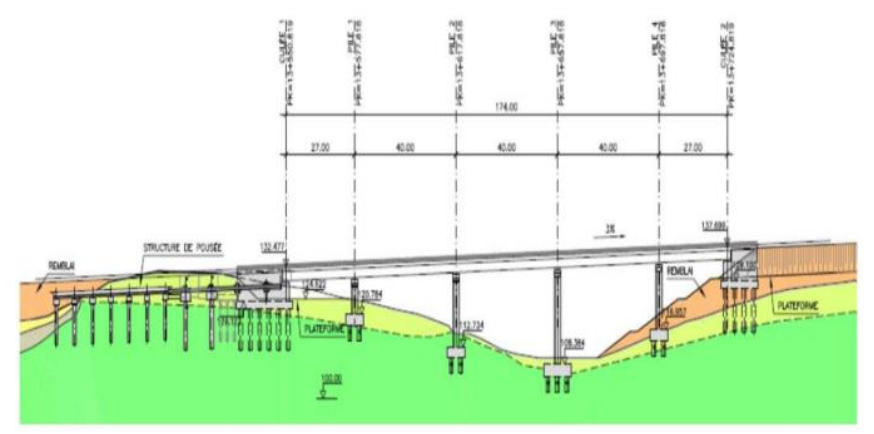

Figure 1. Longitudinal view of the rail bridge

The span structure with a ballast ride is made in the form of a continuous box-section beam of Ferro-concrete preliminary 
intense. The overall width of the bridge deck is $10,80 \mathrm{~m}$, the depth of box section is $2,6 \mathrm{~m}$, the bottom slab width is $4,6 \mathrm{~m}$ and the track centerline spacing is $4.00 \mathrm{~m}$, general for the entire line. In terms of the span structure is located in a curve with a radius of $1060 \mathrm{~m}$ (Figure 2).

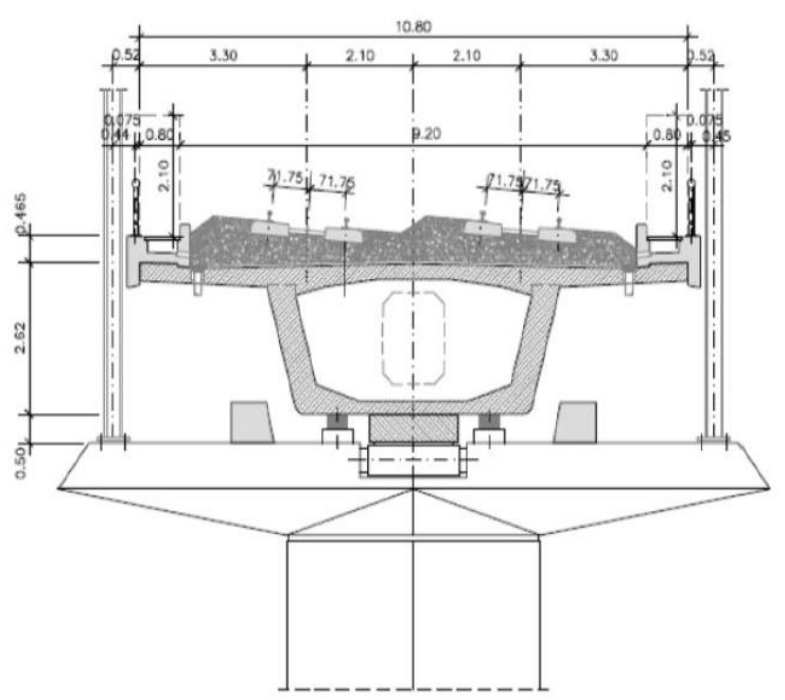

Figure 2. Transversal section of the deck of Rail Bridge

\section{DESCRIPTION OF THE DESIGN MODEL}

As is known [1,2], the main factor of the dynamic impact of the temporary load on the elements of bridge structures in high-speed rail traffic is the pulsation of the deflections of the span structure, which at high speeds of rolling stock may have an unfavorable resonant character.

To study the dynamics of the bridge, an approximation of the actual construction of the span structures and supports by spatial core elements was used (Figure 3) [3, 4]. Using the core model significantly reduces the dimension of the problem, and, consequently, the calculation time.

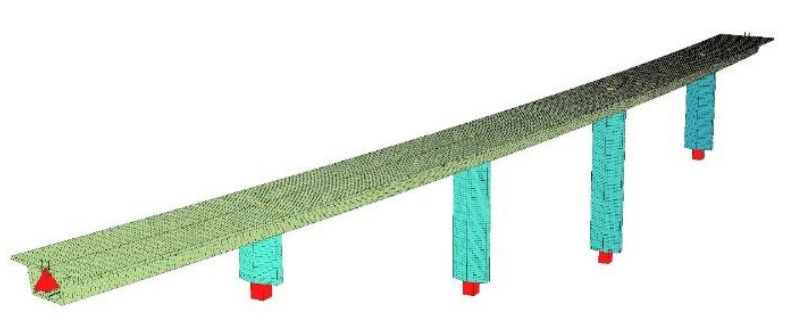

Figure 3. The Calculation (design) model of the bridge

The evolution process of train-bridge dynamic interaction model is described briefly, from the simplest moving constant force model to the sophisticated train-track-bridge dynamic interaction model (TTBDIM) [5]

When performing practical engineering calculations, in most cases, to solve the problem of rolling stock passing through the span, the mobile load can be modeled as a group of constant forces corresponding to the high-speed train diagram (Figure 4) [2,4]. The results obtained quantitatively and qualitatively characterize the dynamic work of the work of structural elements of the superstructure and require minimal labor costs.

The model consists of beam finite elements that simulate the span and supports.

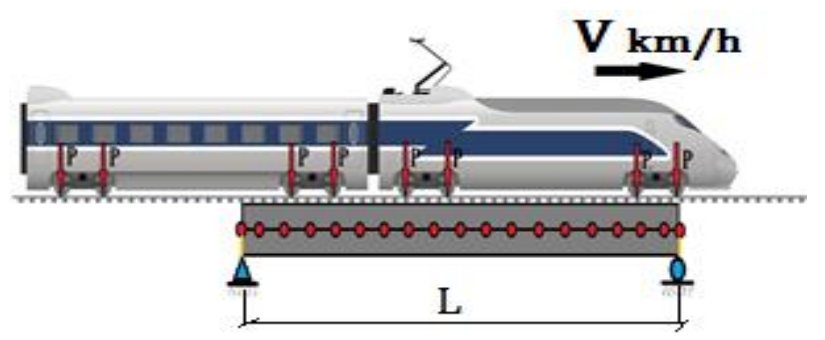

Figure 4 - Model load «moving forces on the structure»

In the course of dynamic calculations, the vertical displacements and accelerations of the span in the middle of the spans were determined. The choice of these parameters makes it possible to analyze the influence of the rolling stock speed on the strusture response value and to make a conclusion about the possible exploitation of the structure at high trafic speeds. Dynamic coefficients were obtained from the value of maximum displacements, which characterize the total magnitude of the increase in forces in the structural elements.

The models of high-speed trains A1-A10 (table 1) [6] were used as the vertical load from the rolling stock in the dynamic calculations of bridge structures.

Table 1 - Parameters of standard trains A1 - A10

\begin{tabular}{|c|c|c|c|c|}
\hline \multirow{2}{*}{$\begin{array}{l}\text { Train } \\
\text { options }\end{array}$} & $\begin{array}{l}\text { Number } \\
\text { wagons }{ }^{1} \text { ) }\end{array}$ & $\begin{array}{c}\text { Length } \\
\text { wagon }\end{array}$ & $\begin{array}{c}\text { Trolley } \\
\text { base }\end{array}$ & $\begin{array}{c}\text { Value } \\
\text { loads on } \\
\text { axis }\end{array}$ \\
\cline { 2 - 5 } & $N$ & $l$ & $D$ & $P$ \\
\cline { 2 - 5 } & $\mathrm{PC}$ & $\mathrm{m}$ & $\mathrm{M}$ & $\mathrm{kN}$ \\
\hline A1 & 18 & 18 & 2 & 170 \\
A2 & 17 & 19 & 3,5 & 200 \\
A3 & 16 & 20 & 2 & 180 \\
A4 & 15 & 21 & 3 & 190 \\
A5 & 14 & 22 & 2 & 170 \\
A6 & 13 & 23 & 2 & 180 \\
A7 & 13 & 24 & 2 & 190 \\
A8 & 12 & 25 & 2,5 & 190 \\
A9 & 11 & 26 & 2 & 210 \\
A10 & 11 & 27 & 2 & 210 \\
\hline 1) The total number of wagons is 4 more (2 locomotives \\
+2 service ones). \\
\hline
\end{tabular}


In order to ensure the stability of the bridge deck, guaranteeing the stability of the track as a requirement of railway traffic safety, the maximum vertical accelerations of the span at the level of the track superstructure are limited on the high-speed bridge structures:

- at the device of a way on a ballast $-3,5 \mathrm{~m} / \mathrm{s}^{2}$;

- at the rigid basis of a track (plate) $-5,0 \mathrm{~m} / \mathrm{s}^{2}$.

\section{PRIMARY RESULTS OF RESEARCH}

The most important dynamic characteristics of bridge structures are the frequencies of their own oscillations, which in fact, characterize the degree of sensitivity of the structure to dynamic loads. Mechanical systems with a distributed mass, which include the span structures of bridges, have an infinite number of natural frequencies, but, as a rule, only the lowest ones have practical significance in research.

If the external dynamic effect has a wide range of frequencies, then the design "chooses" and responds only to frequencies near its own frequencies. This fact determines the paramount importance of the correct determination of the set of natural frequencies of the vibrations of the structure under study during the dynamic impact of the load on the bridge structures.

The $n$-th mode of vibration of the beam is described by:

$$
\begin{aligned}
& v_{n}(x, t)=\sin \frac{n \pi x}{l}\left[A_{n} \cos \frac{n^{2} \pi^{2} c}{l^{2}} t+B_{n} \sin \frac{n^{2} \pi^{2} c}{l^{2}} t\right] \\
& \omega_{n}=\frac{n^{2} \pi^{2} c}{l^{2}} ; \mathrm{c}=\sqrt{\frac{E I}{\rho S}},\left(\mathrm{~m}^{2} / \mathrm{s}\right) ;
\end{aligned}
$$

Where $\omega_{n}$ - vibration, pulsation modes, $(\mathrm{rad} / \mathrm{s})$; $l$ - element length, (m); E- Young's modulus of beam materials, $\left(\mathrm{N} / \mathrm{m}^{2}\right)$; I- quadratic moment of the section $\left(\mathrm{m}^{4}\right)$; $\rho-$ density $\mathrm{kg} / \mathrm{m}^{3}$.

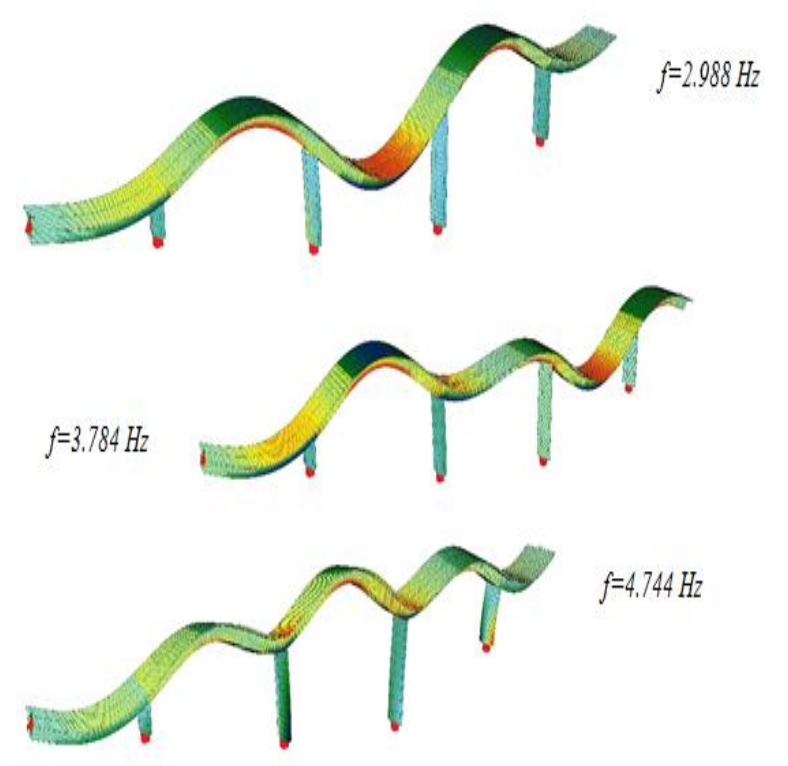

Figure 5. Basic natural modes of vibration of the bridge and corresponding frequencies
When performing dynamic calculations, a speed range from $100 \mathrm{~km} / \mathrm{h}$ to the estimated maximum speed was considered. The estimated maximum speed is taken $20 \%$ higher than the design maximum speed on the highway.

To demonstrate how to analyse the dynamic response of a high-speed train moving over consecutive bridges. The authors [7] have performed the analysis on two existing bridges: a simply supported Taiwan HSR bridge, and a threespan continuous Korea HSR bridge. They obtained that both types of bridges are capable of supporting HSR trains at speeds up to $400 \mathrm{~km} / \mathrm{h}$ with negligible carbody displacements and accelerations. This speed is greater than the current service speed of $300 \mathrm{~km} / \mathrm{h}$.

In the case under study, the maximum design speed was assumed to be $250 \mathrm{~km} / \mathrm{h}$, therefore the estimated maximum speed was $300 \mathrm{~km} / \mathrm{h}$.

Resonant modes of oscillations of the span structure occur when the coincidence or multiplicity of the frequency of the dynamic impact of the train with the natural frequency of oscillations of the span structure. According to this conclusion, it is possible to determine the "critical" or resonance speeds of the train $[8,9]$, at which the specified phenomena will be observed:

$V_{\text {crit. }}=\frac{f_{i} \cdot l}{k}, \quad k=1,2,3$

Where $V_{\text {crit }}$ - critical speed on bridge;

$f_{i}-\mathrm{i}$-th frequency of natural oscillations of the span, $(\mathrm{Hz})$;

$l$ - The length of the high-speed train wagon, (m).

The exact solution of the dynamic problem of passing a moving load is very laborious; therefore, with real design and calculations, they resort to the modeling of the bridgetrain system in software packages implementing the finite element method (FEM). In the present work, the Sofistik software was used for numerical simulation of dynamic problems.

Below (Figures 6 and 7) are presented the results of the dynamic calculations of the bridge. The graphs show the dependences of the maximum dynamic coefficients and vertical accelerations of the span structures in the middle of the span, depending on the speed of movement of various trains.

The European design code for bridges prescribes the value of the dynamic coefficient to be determined by the formula:

$\Phi_{3}=\frac{2,16}{\sqrt{L_{\Phi}}-0,2}+0,73 \leq 2.0$

Where $L_{\Phi}$ - Determining length, associated with $\Phi, \mathrm{m}$; $L_{a}$ - Average span of the structure, $34,80 \mathrm{~m}$;

$\Phi_{3}$ - Dynamic coefficient adopted for the case of a low quality of the path on the bridge. 
$1-2$
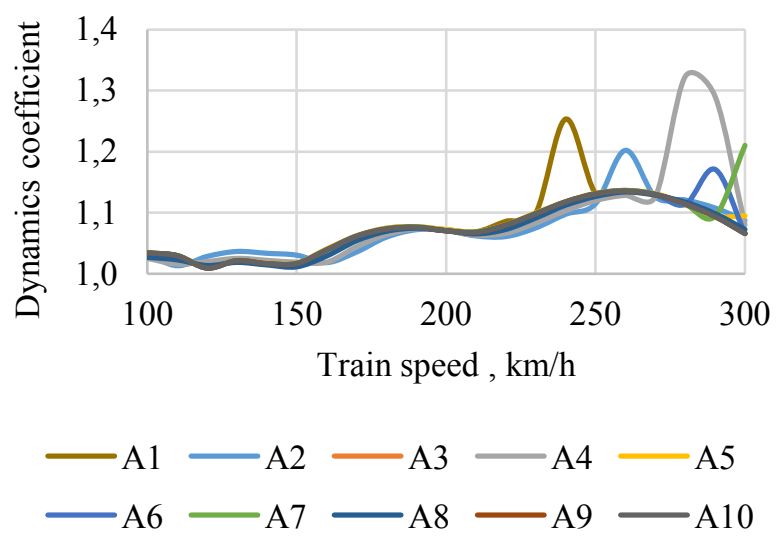

$2-3$

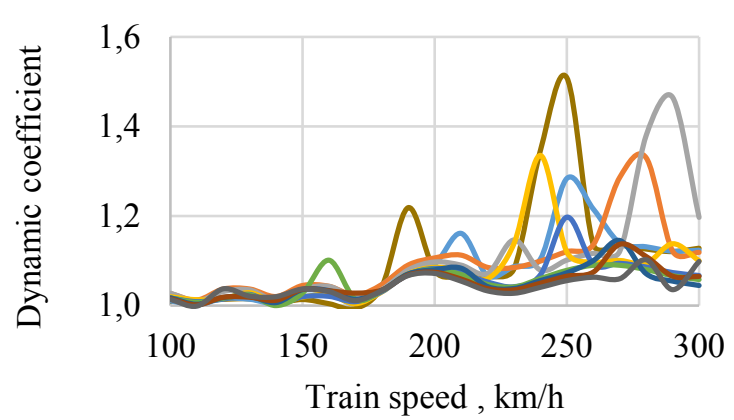

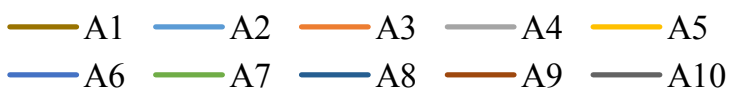

$3-4$

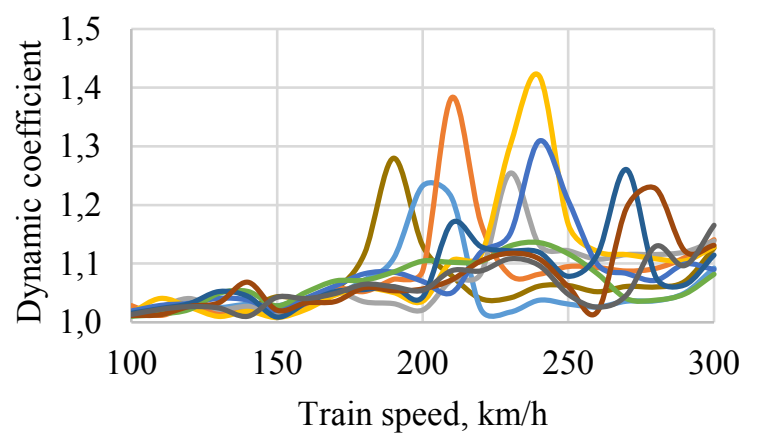

$\longrightarrow \mathrm{A} 1-\mathrm{A} 2-\mathrm{A} 3-\mathrm{A} 4-\mathrm{A} 5$

$-\mathrm{A} 6-\mathrm{A} 7-\mathrm{A} 8-\mathrm{A} 9-\mathrm{A} 10$
4-5
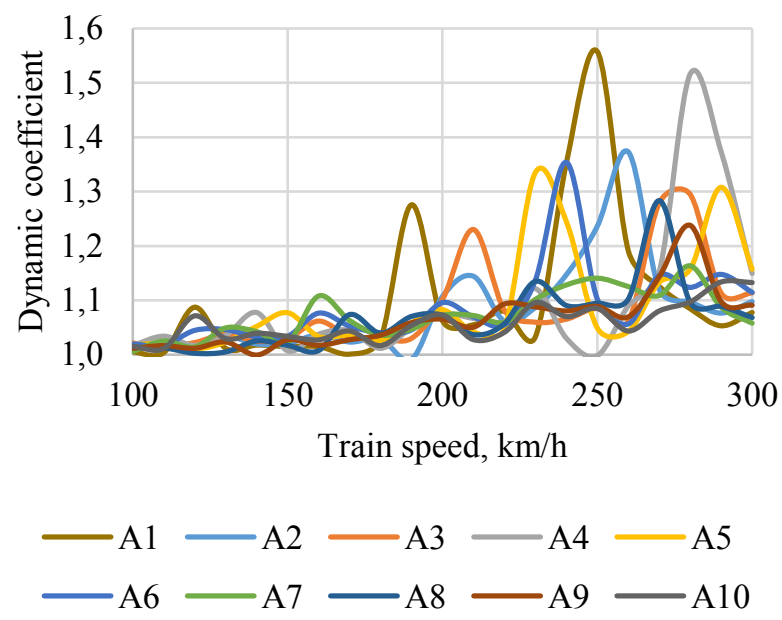

$5-6$
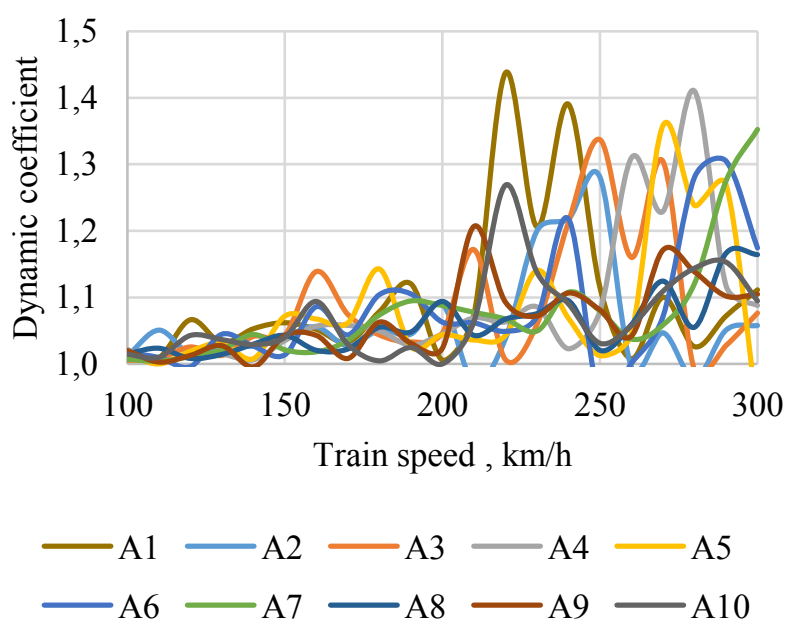

Figure 6. Dependence of the dynamic coefficient on movements in the middle of the bridge (viaduct) spans on the train speed A1-A10

$1-2$

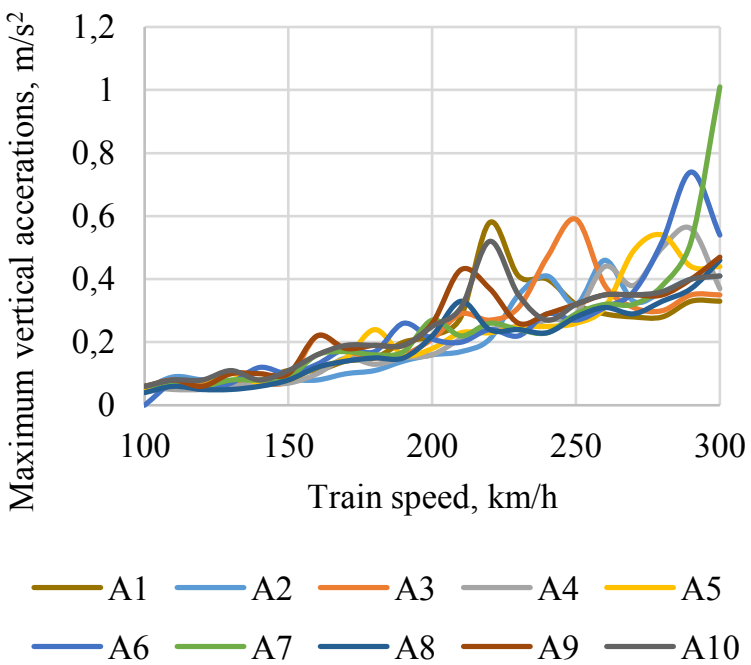


$2-3$

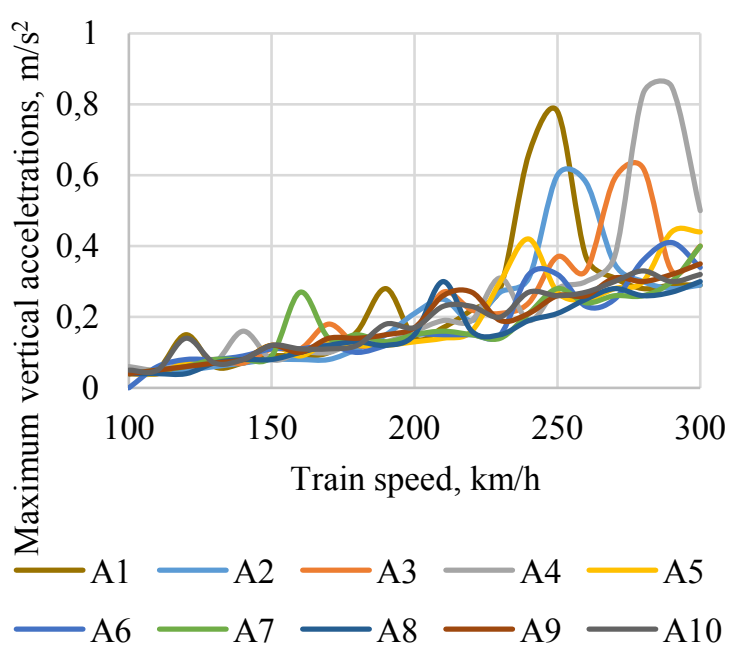

$3-4$

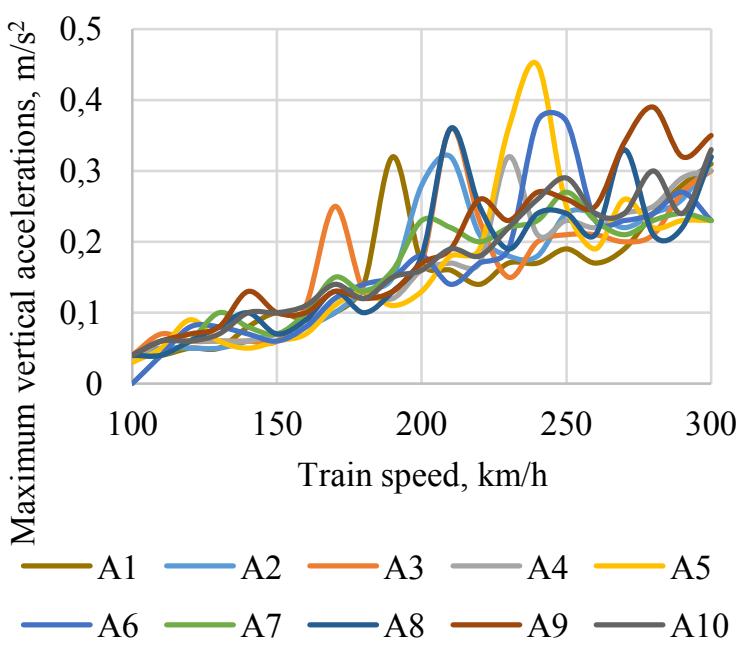

$4-5$

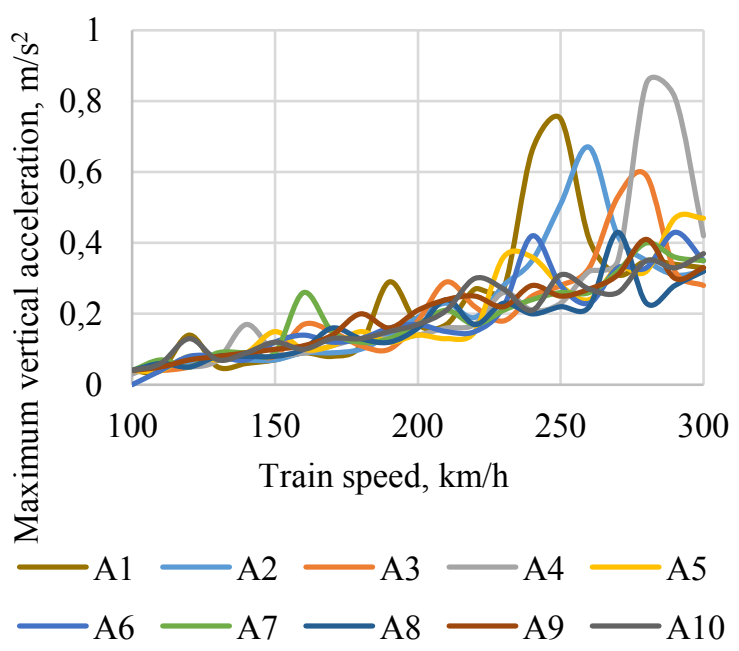

$5-6$

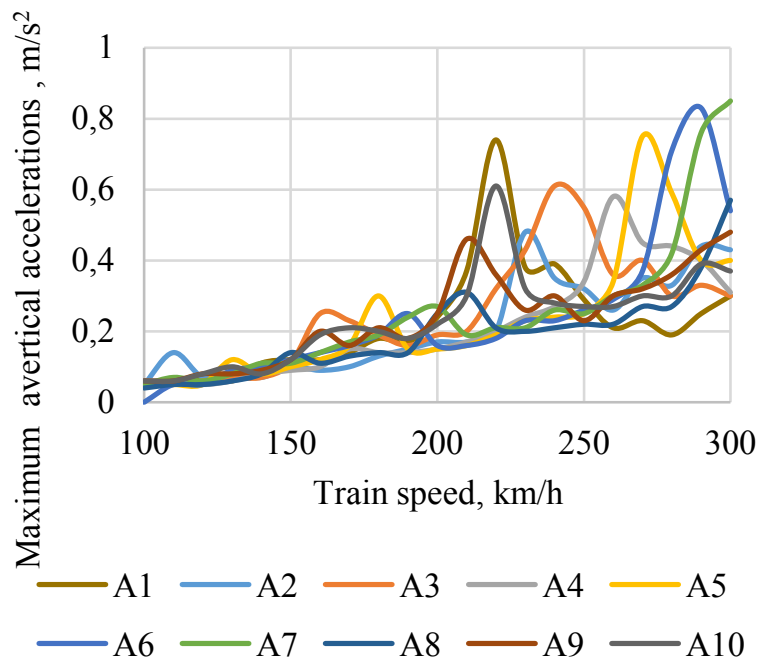

Figure 7. Dependence of the maximum vertical accelerations in the middle of the viaduct spans on the train speed A1-A10

To compare the dynamic work of continuous construction of span structure compared with the split (discontinuous) systems; on figures 8 and 9 are showed the dependences of the maximum dynamic coefficients and vertical accelerations for split span structures of length $27 \mathrm{~m}$ and $40 \mathrm{~m}$ in the middle of spans depending on the speed of various trains.

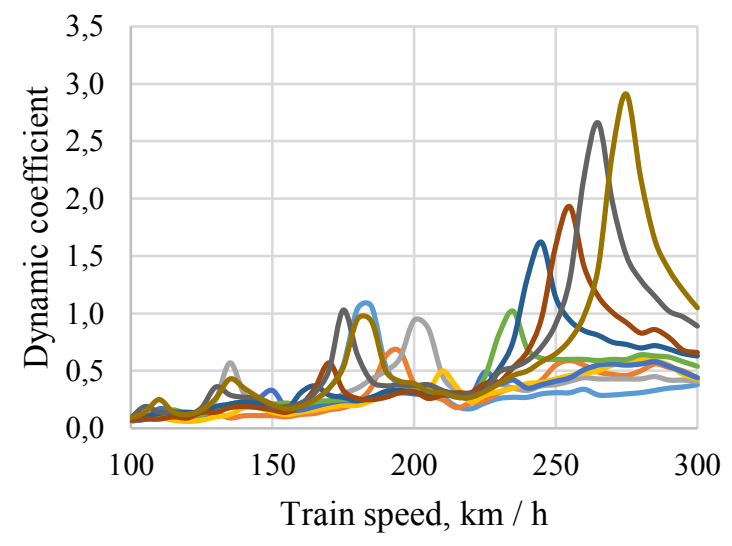

Fig.8. a) 


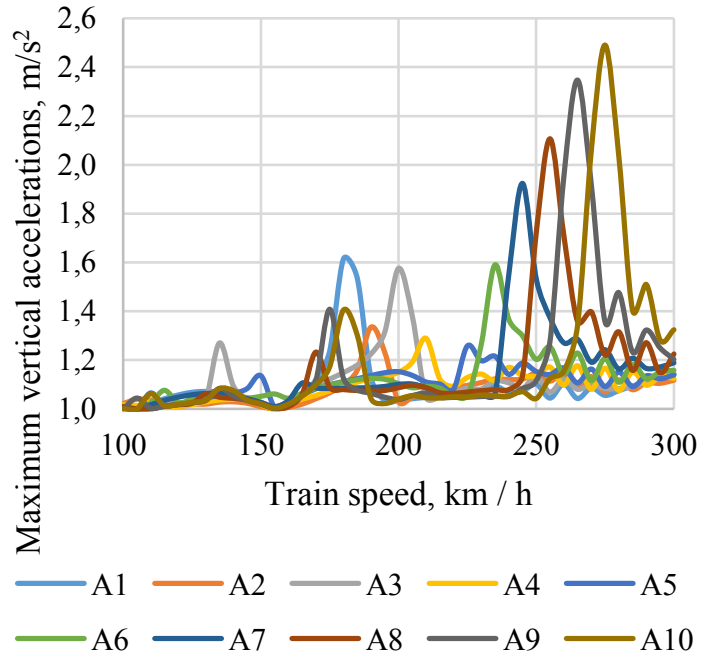

Fig. 8. b)

Figure 8. a, b). Dependence of the dynamic coefficient and maximum vertical accelerations in the middle of the split
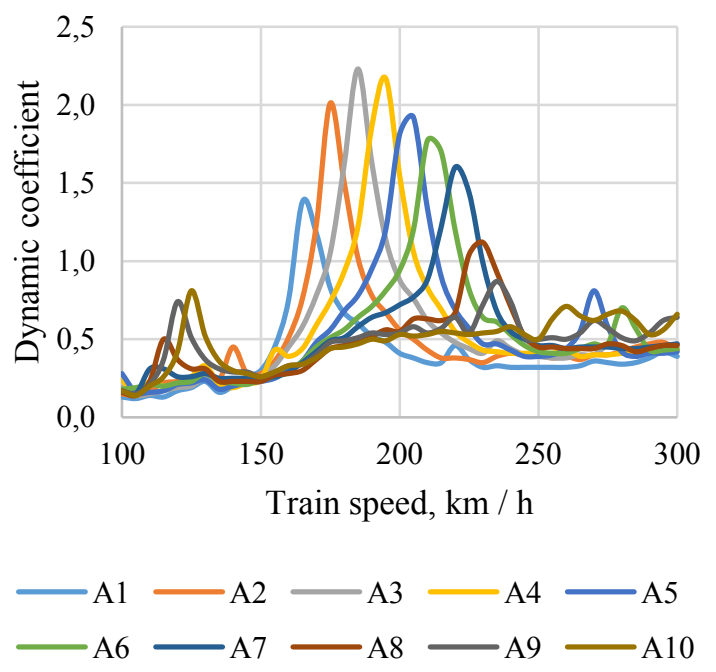

Fig.9. a)

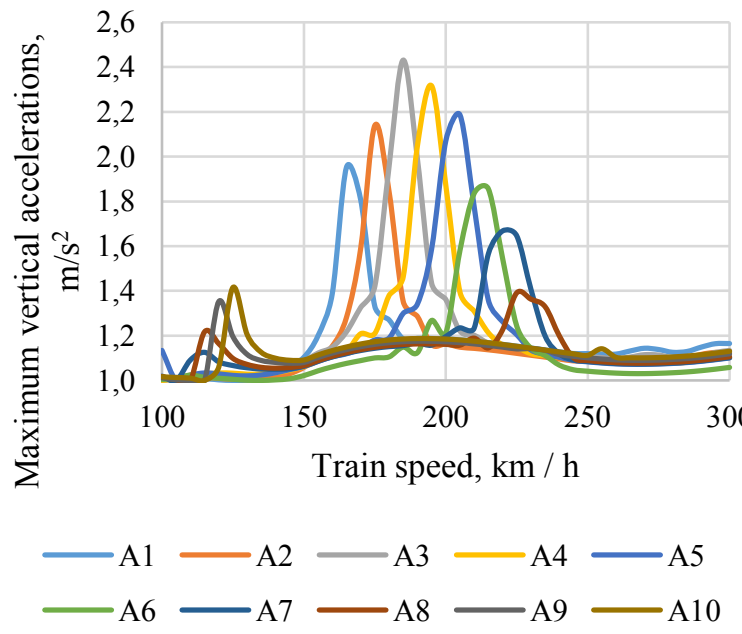

Fig.9. b)

Figure 9. a, b. Dependence of the dynamic coefficient and maximum vertical accelerations in the middle of a split span structure of $40 \mathrm{~m}$ from the speed
In this end, when designing high-speed rail lines, the main parameters of the rolling stock should be determined. The use of a limited reduce the consumption of materials, which leads to a significant economic effect in the construction of the entire line $[10,11]$.

Moreover, due to the high technical and technological performances of unmanned aerial vehicles (UAVs) which allow them to accomplish rescue tasks, Surveillance, etc., with precision and speed in the best possible way $[12,13]$ Their use in areas such as the monitoring of mobility of highspeed train traffic and especially in railway infrastructure bridges are paramount and efficiency.

In the other hand in their work [13] they mentioned model turned out to be computationally efficient, as real dynamic

In this end, when designing high-speed rail lines, the main parameters of the rolling stock should be determined. The use of a limited reduce the consumption of materials, which leads to a significant economic effect in the construction of the entire line $[10,11]$.

Moreover, due to the high technical and technological performances of unmanned aerial vehicles (UAVs) which allow them to accomplish rescue tasks, Surveillance, etc., with precision and speed in the best possible way [12] Their use in areas such as the monitoring of mobility of high-speed train traffic and especially in railway infrastructure bridges are paramount and efficiency.

In the other hand in their work [13] they mentioned model turned out to be computationally efficient, as real dynamic simulation time was introduced.

\section{CONCLUSION}

The completed studies allow us to draw the following conclusions:

With an increase in train speeds of up to $300 \mathrm{~km} / \mathrm{h}$, resonant modes of oscillation of span structures may appear. In some cases, the dynamics coefficients for the studied structure can reach 1.5 and more. The level of the oscillation does not disturb the stability of the ballast. The criterion for ensuring the stability of the bridge desk is the magnitude of the maximum accelerations of the span structure at the level of the carriageway (bridge desk).

Continuous span structures work much better in the perception of moving loads from high-speed trains than split ones [14]. This is due to the higher rigidity of the structure. Dynamic forces in split span structures are significantly higher than in continuous ones. It should be noted that continuous span structures require an individual approach to design and dynamic design, which significantly increases the labor expenditures (costs) for their design. For complex structures of span structures, it is necessary to consider cases in which the train passes in different directions, since the work of the structure due to the density of the natural frequency spectrum is very complex. 
When designing bridge structures on lines with high-speed train traffic, it is necessary to organize a monitoring system that allows to maintain the regulatory (design) levels of reliability, safety and durability of structures.

\section{REFERENCES}

[1] A. V. Benin Osobennosti proektirovaniya i stroitel'stva mostov vysokoskorostnoy zheleznodorozhnoy magistrali «Moskva-Kazan'» / A. V. Benin, L. K. D'yachenko, V. N. Smirnov // Izv. Peterb. un-ta putey soobshcheniya. - 2015 [2] V. N. Smirnov Mosty na vysokoskorostnykh zheleznodorozhnykh magistralyakh / V. N. Smirnov, A. A. Baranovskiy, G. I. Bogdanov, D. E. Vorob'yev, L. K. D'yachenko, V. V. Kondratov // SPb.: PGUPS. - 2015. - 274 S.

[3] V. N. Smirnov. Osobennosti proektirovaniya mostov na vysokoskorostnykh zheleznodorozhnykh magistralyakh / V. N. Smirnov, A. O. D'yachenko, L. K. D'yachenko // Byulleten' rezul'tatov nauchnykh issledovaniy. - 2017. - № 3. - S. 69-81.

[4] S. V Chizhov. Otsenka bezopasnosti mostov s uchetom dinamiceskogo faktora nadezhnosti / S. V. Chizhov, E. T. Yakhshiev, L. K. D'yachenko // Izv. Peterb. un-ta putey soobshcheniya. - 2016. - № 2 (47). - S. 247-254.

[5] Wanming Zhaia, Zhaoling Han a, Zhaowei Chen a,b, Liang Linga and.Shengyang Zhua. Train-track-bridge dynamic interaction: a state-of-the-art review. VEHICLE SYSTEM DYNAMICS 2019, VOL. 57, NO. 7, 984-1027 https://doi.org/10.1080/00423114.2019.1605085

[6] R. Delgado. Assessment of the dynamic response of highspeed railway bridges in interoperable lines Dynamics of high-speed railway bridges / R. Delgado, R. Calçada, D. Ribeiro, J.R. Pinto \& H. Figueiredo, I. Faria // CRC Press. Balkema Taylor \& Francis Group, London - 2009 - p. 173197.

[7] Gu. Gunmo, Yang Fuheng. Dynamic Response of HighSpeed Train Moving on Consecutive Bridges. KSCE Journal of Civil Engineering (2019) 23(9):4047-4062 Copyright (C) 2019 Korean Society of Civil Engineers. DOI 10.1007/s12205-019-2028-4-4047

[8] L. K. Dyachenko. Dinamicheskie raschety proletnykh stroeniy mostov VSM pri dvizhenii passazhirskikh poezdov so skorost'yu do $400 \mathrm{~km} / \mathrm{ch} / \mathrm{L}$. K. D'yachenko // Novye tekhnologii $\mathrm{v}$ mostostroenii (ot proshlogo $\mathrm{k}$ budushchemu): Sb. trudov Mezhdunar. nauch. -tekhnich. konferentsii - SPb.: PGUPS. - 2015. - s.91-97.

[9] V. N. Smirnov. Rezonansnye kolebaniya proletnykh stroeniy mostov na vysokoskorostnykh zheleznodorozhnykh magistralyakh / V. N. Smirnov, L. K. D'yachenko, E. A. Evstigneev // Novye tekhnologii $\mathrm{v}$ mostostroenii (ot proshlogo k budushchemu): Sb. trudov Mezhdunar. nauch. tekhnich. konferentsii - SPb.: PGUPS. - 2015. - s.67-74.

[10] L. K. Dyachenko. Normirovanie dinamicheskogo koeffitsienta $\mathrm{k}$ vremennoy nagruzke pri raschete mostov na vysokoskorostnykh zheleznodorozhnykh magistralyakh/L.
K. D'yachenko, A. V. Benin, V.N. Smirnov // Byulleten' rezul'tatov nauchnykh issledovaniy. - 2017. - № 3. - S. 15-27. [11] L. Dyachenko. Regulation of the dynamic live load factor for calculation of bridge structures on high speed railway mainlines / L. Dyachenko, A. Benin //Civil and environmental engineering. Vol. 13, Issue 1-2017.

[12] L. SETLAK, R. KOWALIK. The Dynamics of the Movement of Formations of Unmanned Aerial Vehicles.

WSEAS Transactions on Applied and Theoretical Mechanics. E-ISSN: 2224-3429. Volume 14, 2019.

[13] L. SETLAK, R. KOWALIK. Modeling and Control of the Engine Turbine for the Purpose of the Electricity Generation. WSEAS Transactions on Applied and Theoretical Mechanics. E-ISSN: 2224-3429. Volume 14, 2019.

[14] L. Dyachenko. An assessment of the dynamic interaction of the rolling stock and the long-span bridges on high-speed railways / L. Dyachenko, A. Benin // MATEC Web of Conferences, $\quad 107 \quad-\quad 2017 \quad$ (DOI: https://doi.org/10.1051/matecconf/201710700014).

\section{Creative Commons Attribution License 4.0 (Attribution 4.0 International, CC BY 4.0)}

This article is published under the terms of the Creative Commons Attribution License 4.0 https://creativecommons.org/licenses/by/4.0/deed.en US 